\title{
Space State on Earth and Beyond: Philosophy, Models, Experience and Prospects
}

\author{
Sergey Krichevsky \\ Doctor of Philosophical Sciences, Professor, S.I. Vavilov Institute for the History \\ of Science and Technology of the Russian Academy of Sciences \\ (Moscow, Russia) \\ E-mail: svkrich@mail.ru \\ https://orcid.org/0000-0002-1094-7770 \\ Sergey Udartsev \\ Doctor of Juridical Sciences, Professor, M. Narikbaev "KAZGUU” University \\ (Nur-Sultan, Kazakhstan) \\ E-mail: sudartsev@mail.ru \\ https://orcid.org/0000-0002-5517-9314
}

The article discusses the philosophical, legal, historical, and technological aspects of the space state, provides definitions, presents classifications, models, suggests examples, and makes forecasts. The general classification of participants in space activities for the purpose of survival and development, as well as the universal classification of space states have been developed. The definitions of space states are given, criteria for classifying space states into different levels and types are proposed, considering the areas and scope of space activities, and their various forms are shown. The prospects and limitations of the space states, their philosophical and technological aspects, including those in the new era of international cooperation, taking into account the possibilities of creating the World Cosmic Union, are briefly reviewed, as well as the futurological aspect of a universal space state is considered.

Keywords: space state, space activities, cosmic civilization, cosmic humanity, classification, model, philosophy of state and law, digital space state Asgardia, evolution

Received: May 16, 2019; accepted: June 12, 2019

Philosophy and Cosmology, Volume 23, 2019: 30-52.

https://doi.org/10.29202/phil-cosm/23/4

(C) Krichevsky, Sergey, 2019

(C) Udartsev, Sergey, 2019 


\section{Introduction}

Advancing the research on the theory and practice of space exploration, the creation of cosmic humanity (see: [Krichevsky, 2012, 2017-2019; Ursul and Ursul, 2018]), space state (see: [Udartsev, 1994, 2012, 2014, 2019a, 2019b; Ursul, 1998, 2016]) in the evolutionary paradigm, we will consider the main aspects related to the space state as a form and technology of the organization of cosmic humanity ${ }^{1}$.

We will briefly present the philosophical, legal, historical, and technological aspects of the space state, the basic concepts, classifications and models, the "rules of the game", examples and forecasts.

In a single system and in an interdisciplinary formulation, we will consider the main aspects of the space state on Earth and beyond in the $20^{\text {th }}-21^{\text {st }}$ centuries, in the process of the evolution of various ideas, forms, types, models, with a brief description of experience, features, problems and prospects in the process of formation and evolution in the paradigm of the cosmic future of civilization and the creation of cosmic humanity.

When analyzing the history of space activities, the current situation and forecasting the future of the space state, the world community and all our civilization on Earth and beyond, the prospects of space humanity, we deal with complex conceptual, legal, socioenvironmental, digital and other models of the past, present and future.

The adequacy and reliability of promising models of the space activities and the cosmic future of humanity raise doubts in comparison with the complex real global socio-political processes, trends and threats to human life on Earth in the $21^{\text {st }}$ century.

Many models (as an auxiliary tool of the cognitive process according to Yuri Baturin, see: [Baturin, 2013]) for research of space technologies and activities, the space state and humanity, as well as the simulation results in the synthesis with practice, create new knowledge, which increase the chances of man and humanity for survival, safe and sustainable development within the scope "Earth + Space" according to the optimistic scenario. The ideas about cosmic power and space (celestial, divine) state appeared in the ancient world (see: [Udartsev, 2012, 2014]). The ideas of the cosmic future of humanity were widely spread in the Russian cosmism of the late $19^{\text {th }}$-early $20^{\text {th }}$ centuries. Nikolay Fedorov, a prominent Russian philosopher, wrote about man as a future "inhabitant and ruler" of cosmic space [Fedorov, 1982: 528]. Alexey Borovoy reflected on the connection of a person with the "universal consciousness", immortality and the ability of a person to "independently complement and improve the universe" [Borovoy, 1920: 42, 86, 97]. The biocosmist Alexander Agienko (writing to the press under the pseudonym Sviatogor) reflected on the infinite creative role of a human in the Universe and the correlation of the ultimate development of human rights with the cosmic era and vast reaches of outer space, see details [Udartsev, 1994]. Konstantin Tsiolkovsky stated that the will of highly developed intelligent civilizations in the Universe "almost agrees with the absolute will of the Universe. Their technical power, in connection with this social organization, made them masters of the world. Through them, the cosmos manifests its power" [Tsiolkovskiy, 1928: 16; see also: Udartsev, 1994: 286-288].

\footnotetext{
${ }^{1}$ The materials of research by the authors involved in studying the theory and practice of space activities, the space state in Russia, Kazakhstan, and the world community are published. In 1991-1993, Sergey Krichevsky participated in the creation of the Russian Space Agency, the development of the Federal Law of Russia "On space activities" (1993), since 2016 he has been participating in the project of a new space state Asgardia. Since the 1990s, Sergey Udartsev has been developing the theory of the space state.
} 
A large number of space states models are also represented in science fiction, cinema, computer games, etc.

The cosmic function of society and the state, the theory of the space state discussed in a number of scientific publications, among which of particular attention are the works of Sergey Udartsev and Arkady Ursul [Udartsev, 1994: 286-288, 2012, 2014, 2019a, 2019b; Ursul, 1998, 2016]. Since 2016, numerous publications have been devoted to the theory and practice of creating a new space state Asgardia has appeared [Ashurbeyli, 2016-2019; Asgardia, 2019; Krichevsky, 2017-2019; Egorov, 2018; Valentina Tereshkova, 2018].

We give here brief definitions of the two basic concepts related to the space state (for more details, see Section 1 and further).

Space state is a state actively participating in space activities.

Space activities are purposeful activities on the development (exploration and use) of outer space using space technologies and equipment.

There are complex issues of interpretation and correlation of concepts, forms, models related to space activit activities, space communities, state, civilization, humanity, and their evolution, among which the following may be highlighted: 1) cosmonautics and space activities within the scope of "man — community — society — civilization"; 2) the purpose and functions of the space state, its role in the formation and evolution of cosmic civilization; 3 ) the ratio of institutions and mechanisms of organization and self-organization in the evolution of cosmic civilization; 4) cosmic community - cosmic state - cosmic civilization; 5) self-organization, organization, directions and factors of evolution, transformation, disintegration, elimination of space communities, states, civilizations; 6) space associations, unions on Earth and beyond; 7) a system of models and forms of cosmic communities, states, countries, and civilizations.

The analysis of the space functions of the state is of vital importance. The general formulation of the problem of cosmic function as a generalized concept of all the activities of a country, a state in the cosmic space, moreover, in the paradigm of sustainable socio-natural development, was made by Arkady Ursul. He first proposed to specifically highlight the cosmic function of the state, gave a detailed justification of astronautics, space activities and the space functions of a human, state, society, civilization, highly organized mind through the category of space exploration needs (see [Ursul, 1998: 326-333]). According to Arkady Ursul: "The need for space exploration ... is now a major category ... And this need is induced by fundamental natural laws, but not just economic or social efficiency, environmental expediency and safety, sustainability of the planetary development of civilization, etc. Apparently, this is a universal need of all the highly intelligent to realize their cosmic function and create integrated systems of the cosmic mind. These space activities of people must enter a new civilizational model of development" [Ursul, 1998: 333]. He also draws attention to the ideas of Konstantin Tsiolkovsky about the spread of the phenomenon of statehood in space: "Implementation of the governmental space function not only transmits the phenomenon of statehood to space but also imparts the very idea of sustainable development with noosphereantropo-cosmism orientation, transforming it, in astronomical sense, into K. E. Tsiolkovskiy's idea of immortality of humanity" [Ursul, 2016: 208].

In the Space Age, there are three interrelated forms of organization and self-organization of space activities of a society (country, world community, humanity) for space exploration for the survival and development of man and humanity through the creation and institutionalization of space communities corresponding to three interrelated sectors of modern society: state, corporations, civil society (by: [Krichevsky, 2019]). 
In the process of initiation and evolution of astronautics and space activities at the initial stage in the first decades of the $20^{\text {th }}$ century, individual researchers, engineers (they created the basics of astronautics theory, first space technologies, technical projects), self-organized the first space communities, scientific and professional societies in several countries of the world. Further, scientific and industrial organizations, authorities and administrations were created in the form of divisions, departments, committees, agencies, ministries in the structures of governments of a number of states during the institutionalization of the "space function" in scientific, military, industrial and other aspects and directions of space activities, creating a new space industry. Then, in a number of countries, state space (aerospace) agencies (e.g., in the USA since 1958), departments, committees, space councils, etc. were formed, which became the special authorized bodies of the states in the field of space activities, management of space industry. At the same time, public and private aerospace, space corporations were developing.

At the stages of formation and development of practical astronautics, space activities have been framed in a number of countries since the 1950s to present - the space function has been institutionalized, these countries and these states have become the "space states."

The main technical criterion for the absolute, complete "space" status of a country or state is an autonomous, independent access to space, the presence of a spaceport, launch vehicles, control and tracking system for spacecraft, launching of a national space object into space. There are currently 10 such states, and their number is gradually increasing. A total of 80 countries in the world have their own satellites, moreover, many of them have ordered and purchased satellites on the space market, including their launch into space by other states (at the beginning of 2019). All countries of the world use the results of space activities (in various volumes, goals, etc.), i.e. they are participants in space activities. ${ }^{2}$

There is a group of foremost leading space countries, states (the USA, Russia, China), which autonomously and independently carry out the whole range of types and directions of space activities in the full life cycle, including manned space flights and long-term human presence in space.

Thus, "cosmicity", in its broad view, the cosmic status of a country, a state, and other actors involved in space activities may be determined by the activities of the participants, but the indicators of the activities are conditional and variable, and they need to be specified in connection with the topic of this article. This issue is discussed in more detail in Section 1.

The number and influence of private space corporations are growing, which, as a rule, exist with the strong support of "their own" space states and significantly influence the development of the space market of products and services, the volumes and rates of cosmization of the economy and the whole society.

Space states and corporations are the main actors - the drivers of the modern sphere of space activities and space industry. Many other organizations (scientific, educational, industrial, etc.) involved in space activities, including numerous independent non-profit space communities of civil society, have significant potential and influence on public consciousness (and through it, the influence on the space states and corporations at the national and international levels).

\footnotetext{
${ }^{2}$ Detailed information about the brief history of space states and other aspects of space activities was published by Ivan Moiseev (2019). "Countries with own space ports, boosters and satellites (sometimes such countries are called "spacefaring nations"). There are ten such countries for today (in brackets is the year of the first successful launch of a satellite): Russia (USSR, 1957), USA (1958), Europe (France, 1965), Japan (1970), China (1970), India (1980), Israel (1988), Iran (2009), DPRK (2012) and the Republic of Korea (2013). European countries (EU, the authors' note) are in one category because their space programs are closely connected"' (cited in: [Moiseev, 2019: 35-36]).
} 
At the same time, these are modern space states, which are the main actors — institutes, integrators and "machines" of space activities of space states, they possess maximum resources, organization and management capabilities, determine goals, priorities, directions and rates of space exploration at the national and international levels.

Implementing the space function of the society, the space state stimulates, supports, and organizes the creation, implementation and use of space technologies and technology for the implementation of space activities and the achievement of goals for the benefit of a human, state and society. Ideally, the space state is an integrator of cosmic knowledge, rules of the game, technologies, machinery, activity, obtaining and using results.

At the same time, the "traditional" space state as a form of organizing space activities of the society to perform cosmic function, creating cosmic humanity is not ideal or absolute and has a number of features and limitations, including those due to the internal problems of specific earthly states, competition for leadership with other states, as well as with powerful and growing private space corporations (e.g., with the SpaceX Corporation, the USA). In the future, the "traditional" space state can be faced with tough competition from the emergence of new forms of "special" space states (for example, similar to the digital space state Asgardia) and the possibility of a new promising organization of space activities of humanity — in the form of the World Cosmic Union [Krichevsky, 2019].

In the subsequent sections of the article, we will single out and briefly consider three important aspects of the space state:

1. The space state as a natural, regular form and social technology of organizing the society, human civilization to perform the "cosmic function."

2. The main positive and negative properties, features, limitations of the space state, including the new examples.

3. Prospects for the space state in the process of evolution of the society, human civilization on Earth and in Space.

\section{Basic Terms and Classifications Related With the Space State}

\subsection{Basic concepts}

Space state is a state that actively participates in space activities, it has national space legislation and government bodies that organize and regulate the participation of its actors in these activities, who are the subjects of national law.

Non-space state is a state that is only a passive participant in space activities.

Space activities are activities for the exploration and use of outer space with the use of space machinery and technologies for the survival and development of a man, state, society, country, humanity (civilization). They cover the full cycle of activities (development, creation of space technologies, technology, production, operation of space infrastructure, obtaining results, rendering services, etc.) and areas of activities (research, communications, telecommunications, navigation, remote sensing, defense and security, manned space flight, etc.).

The space status of a country, a state, and other actors involved in space activities (corporations, space communities, including scientific, educational organizations, etc.) is determined by the real activities of the participants, but the activity indicators are conditional: from the maximum among the leaders to the incomplete number or to individual directions among the rest of actors.

All participants in space activities are divided into 2 groups: a) active (manufacturers); 
b) passive (consumers). Moreover, producers can be and are consumers in the space market ${ }^{3}$. In the process of developing the space activities and the space market on Earth, an increasing number of its participants are becoming active space actors.

\subsection{Classifications}

1.2.1. General classification of organizations - participants in space activities for the purpose of survival and development on Earth and Beyond

The "General Classification of Organizations-Participants in Space Activities for the Purpose of Survival and Development on Earth and Beyond" (Sergey Krichevsky, 2019) has been developed and presented - see the Table. It shows an important place of the space state in a complex system of forms (by institutions), types (by area), statuses and structures (by activities and characteristics) of all organizations of human civilization and other (hypothetical) extraterrestrial civilizations. This classification is comprehensive and open to additions and corrections.

There are three possible main types of the space state (in terms of existence space): 1) on Earth (terrestrial);2) on Earth and Beyond, within the scope of Earth + Space; 3) beyond Earth (autonomous, independent of Earth and earthly human civilization, including hypothetical space states of extraterrestrial civilizations, etc.).

At the same time, "transitional" (self-proclaimed, unrecognized) space states have the right to exist, e.g., in the form of a virtual digital space state, based on Earth's resources, with placing information about it (its institutions, citizens).

Table. General classification of organizations - participants in space activities for the purpose of survival and development on Earth and Beyond (Sergey Krichevsky, 2019)

\begin{tabular}{|c|c|c|}
\hline $\begin{array}{c}\text { Forms of } \\
\text { organizations } \\
\text { (by institutions) }\end{array}$ & $\begin{array}{c}\text { Types of } \\
\text { organizations } \\
\text { (by area) }\end{array}$ & $\begin{array}{l}\text { Statuses and structures of organizations } \\
\text { (by activities and features) }\end{array}$ \\
\hline $\begin{array}{l}\text { A. States } \\
\text { B. Corporations } \\
\text { (national and } \\
\text { transnational). } \\
\text { C. Non-profit } \\
\text { communities of all } \\
\text { levels. } \\
\text { D. Countries } \\
\text { E. Civilizations } \\
\text { F. Associations, } \\
\text { alliances, unions } \\
\text { of all levels. }\end{array}$ & $\begin{array}{l}\text { I. Earth's } \\
\text { II. Space } \\
\text { a) on Earth; } \\
\text { b) on Earth + } \\
\text { Beyond Earth; } \\
\text { c) beyond Earth } \\
\text { (at all scales of } \\
\text { space: in the } \\
\text { Solar System, } \\
\text { the Galaxy, the } \\
\text { Universe). }\end{array}$ & $\begin{array}{l}\text { 1. Participants of the space activities of humanity: } \\
\text { 1.1. passive (consumers) - "non-cosmic": } \\
\text { Non-cosmic communities of humanity. } \\
\text { Non-cosmic corporations of humanity. } \\
\text { Non-space states of humanity. } \\
\text { 1.2. active (producers, including those who are } \\
\text { consumers of the space market) - "cosmic": } \\
\text { Cosmic communities of humanity. } \\
\text { Cosmic corporations of humanity. } \\
\text { Space states of earthly humanity, including: } \\
\text { Foremost, leading space states, countries of earthly } \\
\text { humanity (the USA, Russia, China); } \\
\text { Other space states, countries of earthly humanity; } \\
\text { New "transitional" space states from earthly to cosmic } \\
\text { humanity (Asgardia). }\end{array}$ \\
\hline
\end{tabular}

${ }^{3}$ The economic aspects of space activities are extremely important, but are not covered by this article. 


\begin{tabular}{|l|l|}
\hline & $\begin{array}{l}\text { World Cosmic Union of humanity (forecast). } \\
\text { Cosmic humanity (forecast). } \\
\text { 2. Other (extraterrestrial) participants of space } \\
\text { activities (hypothesis): } \\
\text { Cosmic communities with different genesis } \\
\text { (hypothesis). } \\
\text { Space states with different genesis (hypothesis). } \\
\text { Extraterrestrial civilizations with different genesis } \\
\text { (hypothesis). } \\
\text { The "Big Ring" of cosmic civilizations (hypothesis). } \\
\text { Highly organized cosmic mind is the supermind of the } \\
\text { Universe (hypothesis). }\end{array}$ \\
\hline
\end{tabular}

\subsubsection{Universal Classification of Space States}

Other classifications of space states are possible. For example, the universal classification of space states, which was developed and proposed by Sergey Udartsev (2019).

For the early stages of the evolution of cosmic civilization, as evidenced by historical experience, the state form can be an optimal form of organization and management of the life activities of humanity and all its constituent parts, with their human and material resources.

To distinguish between various related concepts and stages of statehood development in the future, it is possible to offer some general terminological differentiation of states with regard to their development as space states.

Modern states:

Earthly states (ES) are those acting on Earth only.

Space states (SS) are those developing space activities (creating and having artificial earth satellites in space, launching space rockets and spacecrafts, conducting various space research, participating in international cooperation in the field of space activities, etc.) and having the special state bodies in their structure, which organize and control military and / or civil space activities, adopting national space legislation irrespective of the degree of their activities and the depth of their penetration into space.

The states of our planet acting not only on Earth, but also in space, can be called the Earth-Space States (ESS) of the Solar system, if space activities have not yet become the main ones for these states.

For the near and relatively more distant future, the space states can be conditionally and generally differentiated into:

Space states of earthly origins of the Solar system can be called the future Earth-Space States, which will primarily function in space.

There is a well-grounded scientific assumption that there are other cosmic civilizations in infinite space that can arise in different ways — through natural generation and evolutionary development, or, as Konstantin Tsiolkovsky [Tsiolkovsky, 2019] believed, through settling the space of other planets and star systems with developed civilizations.

As a more complete model and a distant forecast, we can assume the following steps and forms of the perspective evolution of the statehood.

By the name of a particular planet - X, Y, etc., the states acting on it only (such as ES), can be called - the states of "Planet $X$ ", the states of "Planet $Y$ ", etc. of the corresponding star system, conventionally $-1,2$, etc. 
The states that have emerged on other planets X, Y, etc., but acting not only on their own planet, but also in outer space, if space activities have not yet become the main ones for these states (like the ESS), can be called X-space, Y-space, etc. of a star system, conditionally, 1, 2, etc., of the states of the corresponding star system.

The space states of the unearthly origin of the known particular planets X, Y, etc., of the corresponding star systems, conditionally, 1, 2, etc., but already operating predominantly not on their own planet, but in space, can be called space X,Y, etc. state planets of the star system 1,2 and so on.

Hypothetical unknown space states may either act in space without identifying them or leave traces of their activities in space.

The states of an unknown planet (or of unearthly origin) of a different star system acting in space can be called space states of an unknown planet of another known or unknown star system.

\section{Space State as a Form of Cosmic Humanity Organization}

\subsection{The development of space activities of humanity and the formation of space statehood}

State evolution is inextricably linked with the evolution of humanity. A human, after their becoming homo sapiens, continued their evolution towards rational and cosmic human, more and more revealing his cosmic nature. Humanity as a phenomenon has always been cosmic in its environment of existence, purpose and perspective identity. The cosmic being of humanity is not only its future. First, humanity has inhabited the planet Earth for thousands of years, rushing at tremendous speed in space together with its star - the Sun around the center of the Galaxy. Secondly, real cosmic humanity is already present and is developing in humanity. This is the domain of space activities, formed and developing at the national and international levels in the $20^{\text {th }}-21^{\text {st }}$ centuries, covering dozens of Earth states, as well as the new unrecognized digital state Asgardia, and their citizens, a large number of cosmic communities, including the professional community of astronauts, thousands of public organizations, associations, academies, etc. engaged in space exploration (see: [Ivanova \& Krichevsky, 2013, Krichevsky, 2012, 2017-2019]). There are thousands of institutes, enterprises, firms, corporations of different countries working in science, design and production in the field of space activities. The process of cosmization of social consciousness and practical activities over the past decades have embraced hundreds of millions-billions of people.

Parallelly and constantly interacting with these institutional entities and trends in the development of society, statehood is evolving, which gradually, by the beginning of the Space Age (since 1957), has revealed its cosmic potential. Moreover, the ideas about the space state have been traced in the history of humanity for thousands of years [Udartsev, 2012, 2014].

Since the 1940s, states are becoming more and more involved in rocket production for military activities, then in preparation for space activities, and in competition in this sphere. The competition between the USSR and the USA peaked during the first planetary wave of space activities in the 1950s — 1970s — during the "lunar race" of the program "Apollo" and ended after the end of the Cold War and the collapse of the USSR in the early 1990s.

The victory in space was the prelude to the US victory in the Cold War and the subsequent collapse of the USSR. The last time the US astronauts were on Moon was in 1972. However, humanity did not have the strength and resources to further develop this breakthrough in science and technology [Medvedev, 2019]. The development of astronautics went wide: development 
of new spacecrafts, including reusable ones; new rocket engines; creation and development of orbital stations; accumulation of the experience of a human's long stay in space (up to one and a half years); improvement of life support systems for astronauts and space medicine; flights of automatic stations to other planets, asteroids, comets; launching optical and radio telescopes into space; development of applied cosmonautics (for telecommunications, remote sensing of Earth, search and positioning systems, testing of medical and biological experiments, etc.); study of the fundamental problems of the space, etc.

Moreover, even today, spaceflight remains a very expensive, risky, one of the most dangerous businesses for people.

Over the past years of the Space Age (over 60 years), tremendous information has been gathered, extensive experience has been gained, new information technologies and equipment have been created, new materials have changed, as well as people's consciousness. Humanity psychologically, intellectually and practically is now better aware of its connection with the space, and the coming cosmic fate.

The legal regulation of space activities by international space law was complemented by the emergence of the national space law. More than 30 countries of the world have national legislation on space activities [Tabanbaeva, 2017]. In addition, the number of such countries is growing. A lag in the national legal regulation of space activities, when the international space law, adopted several decades ago, is likely to clearly lag behind its accelerated development, may adversely affect the development of this sphere. This can also be seen on the example of Russia, where the draft law "On entrepreneurial activities in the domain of the research and use of outer space" was among 19 laws introduced into but not adopted by the State Duma [Zhukov \& Moiseev, 2018].

It is important that the development of the sphere of space activities has approached the need for a public-private partnership and the possibility of broader attracting of private capital to the astronautics. Private capital has not yet replaced and will not replace the state in this area in the main and strategic costly directions of astronautics, but it began to win its niche for the development of competitiveness and quality improvement in a number of space projects. However, meanwhile private astronautics receives an insignificant part of state funding for state orders. Nevertheless, in the US, private space activities, having received timely legislative support, began to accelerate the development. World-class leaders such as Ilon Musk and Jeffrey Bezos, capable of promoting global and superglobal projects, appeared on the scene.

On the basis of the above considerations, under the conditions of a new, the third over the past two centuries, rising wave of science in the $21^{\text {st }}$ century [Kaku, 2019], a new upsurge in the space activities of humanity begins in the world. The objectives of this stage of enhancing space exploration, which will apparently last several decades, are more advanced: return to the Moon; creation of circumlunar and lunar stations, permanent lunar settlements; manned flights to Mars and the beginning of its colonization; development of space tourism. This is the beginning: the development of minerals on the Moon and other space objects, especially on asteroids; creation of spaceports in space; the construction of large space settlements in Earth orbit; new studies of the Solar System and interstellar space by automatic stations; development of basic and applied space research. At the same time, the scientific literature points out the following: in the $21^{\text {st }}$ century, the main goal of space activities is the beginning of human settlement beyond the Earth, in the Solar System, and not just interplanetary flights, which are ultimately not a goal, but a means (see: [Krichevsky, 2012: 286]). 
The prospects of the Space Age are seen in the transition to its third period from the 2020s, when superglobal projects will be implemented on the basis of new environmentally friendly technologies with a new technological structure [Krichevsky, 2018].

New space race and the competition of developed countries in the domain of space exploration will unfold against the backdrop of increasing global instability. This is pointed out, for example, in the National Intelligence Strategy, prepared by experts of the US private intelligence and analysis company "Strategic Forecasting Inc." (abbreviated Stratfor), presented by National Intelligence director Daniel Coats to the members of the Intelligence Committee of the United States Senate. This document stresses that "in the coming years, the world will enter a new era of global competition, which could end in a big war" (see the review: [Ivanov, 2019]). Under these conditions, space activities can play an important role not only for the development of competition, but also for uniting efforts in large global projects, for certain smoothing over contradictions.

To combine the efforts of several countries in the implementation of large space projects is objectively necessary because of their high cost. These costs will pay off over time, but are currently a big burden on the budgets of particular countries. Thus, the creation of a lunar base is estimated at 110-140 billion dollars, and an expedition to Mars will cost, according to various estimates, from 300 to 500 billion dollars [Vaganov, 2019].

At a new stage of space exploration, the scope of competing countries-leaders in this field is expanding (the USA, China, Russia, India, EU, Japan, etc.). All new countries are involved in space activities. Experts distinguish a number of new space states, in particular, Luxembourg (an actively developing country in this domain), Israel, Azerbaijan, the United Arab Emirates, New Zealand, Australia, Iran, Brazil, North and South Korea [Egorov, 2018]. The deployment of all the main components of the space activities in Kazakhstan, where the Baikonur cosmodrome is located, is being completed.

The state bodies are being created and developed, whose functions include the management and regulation of space activities. Dozens of countries around the world already have their own national space ministries, committees, agencies, centers, offices, etc. (e.g., about the evolution of space administrations in Kazakhstan, see: [Kukieva, 2017]).

In the world, there are two dozen cosmodromes, and almost all of them are state-owned. The United States has six spaceports, Russia - five (including one under construction), the PRC - four, the DPRK and Japan - two in each. In addition, there are mobile spaceports (surface, submarine and air).

In the coming decades, the upcoming real beginning of the extraction, processing, development of space resources, creation and development of the space industry not only on Earth, but also in outer space, opens up truly fantastic opportunities, given the unlimited number and values of these resources. Thus, an asteroid that flew near Earth in 2015, according to experts, contained 90 million tons of platinum worth $\$ 25-50$ trillion [Kaku, 2019: 92], which is significantly more than the largest national debt accumulated by the USA over the decades.

The main issue here is to ensure the profitability of these activities, the creation of appropriate technologies and transport. In the case of solving these problems, humanity will be able to make a leap, unprecedented in history, in the development and distribution in space. Apparently, sooner or later it will become possible. In addition, this is primarily the state, which will be a necessary tool for restoring order, controlling global and national security, for protecting and supporting private capital that is involved in the extraction and processing, transportation, storage and use of space resources and products from them. 
At present, space troops have been created in Russia, the USA and the PRC. There exists a real threat of space wars in the future. This requires active renewal of international law, the creation of new international legal acts to ensure global and space security.

Obviously, over time, there will be an ingrowth in space activities not only of the armies of the leading states and other developed countries, but also of many other state bodies (law enforcement, control, judicial, organizing production, science, tourism, transport and communications).

The information society has significantly changed the state and forms of implementation of its functions, some of them are automated. The management of technical and social processes at a considerable distance becomes real. The state is adapting to the new situation, the means and technologies of control, management of main spheres of public life are being modernized, "when forming the digital future, the role of the state will only increase" (by: [Belyaev, 2019]).

\subsection{Natural evolutionary and accelerated, artificially modelled creation of space states, their forms}

At the present stage of scientific and technological development and expansion of space activities, the leading earthly states, having gone a long way of natural evolution, began to gradually transform themselves into cosmic nations (about formation of the space state, see: [Udartsev, 2019a; 2019b]). This process will accelerate as a share of participation in space exploration in the activities of states increases. Their further evolution will inevitably be associated with an ever-expanding sphere of activities in space, their participation in the organization of its transformation. In the long term, states will emerge as an organizing force for the participation of humanity in cosmic evolutionary processes.

The beginning of the process of space states formation under the conditions of intense development of electronic information technologies stimulates and, partly, provokes the emergence of models of accelerated and artificial creation of space statehood. The first such space state, which appeared without long historical evolution, by the will of its founder and a group of people supporting it (and in this sense, artificially and rapidly) in 2016, was the unrecognized Space State, the Kingdom of Asgardia (see: [Asgardia, 2019]).

Modern, naturally developing space states may be different in their form. These include constitutional monarchies (Japan, Great Britain), and republics with fairly strong heads of state (the USA, Russia ${ }^{4}$, the PRC, France, India); federations (the USA, Russia, India) and unitary states (the PRC, France); large in territory and population (China, India, Russia, the USA), smaller (France, Japan) and very small (Israel, Luxembourg). However, all of them are technically and economically developed strong states. As a rule, leaders in this sphere are those from among the states-world leaders and the states, which earlier, faster and more successfully than others have integrated into modern scientific, technical, industrial development. At the same time, the entry of a large number of states into the domain of space activities "dissolves" the more homogeneous qualities of the leading states in the process of the formation of space statehood by a motley composition of other member states of space activities. The formation of the space industry, the organization of space activities, the implementation of large-scale space programs and projects, as well as the advancement

${ }^{4}$ According to Igor Ashurbeyli, "Russia needs a constitutional monarchy — a parliamentary republic with a young, about 40 year-old king" [Ashurbeyli, November 15, 2017]. However, as history shows, there are a number of other - republican forms of government, in which there is no less strong power of the head of state than in the monarchy. 
into outer space require the participation of high-tech states. A successfully developing space state at the present stage should also be strong, legal and effective (for the theory of a strong state, see, e.g. [Fukuyama, 2006; Kerimov \& Kuksin, 2017; Ponkin, 2018; Malko \& Zatonskii, 2018]). A weak, fragile state is not able to compete in this sphere with strong states and will inevitably lose to them, but it can also break up. Modern space states-leaders are characterized by state forms with a strong central authority.

At the same time, a big plus is the combination of a strong and efficient state with active participation in space activities, including government orders, private business. Parallel and competitive development of public and private space exploration gives maximum effect. And in this respect, the current world leader in this field, the United States, is ahead of other countries.

High level of technical development of space civilization, the expanding scope of its activities, huge human, material, technical and energy resources will require in the long term an even more powerful and efficient state. It is the state that will participate in restoring order and ensuring the safety of people, technology, property, environment, cultural values on the scale of vast outer space, in its transforming.

The space state will be an important tool for this, but not omnipotent, it will always need the strength and creative support of society. For more information about the prospects of the space state, see Section 4.

\section{New Space State Asgardia: Contours and Features of the Constitutional Model and Practice}

\subsection{A brief history of the first digital space state}

Modern states have a long history. Under the conditions of the unfolding Fourth industrial revolution and the information society, there are hopes to overcome some contradictions of political development as well as to organize a society on a new basis. Vanguard models of the state are being invented with a wide use of digital technologies. One of such projects is Asgardia.

On October 12, 2016, Igor Ashurbeyli, announced the establishment of a virtual Space Kingdom Asgardia at the press conference in Paris.

In June-September 2017, the Asgardia Constitution was adopted in the electronic referendum of the Asgardians. From February 1 to May 20, 2018, the first elections of the Asgardia Parliament were held, on June 24-25, 2018 there were the $1^{\text {st }}$ (in-person) Session of the Parliament and the inauguration of the Head of State in Vienna, on October 10-12, 2018 the second (for the first time, a digital, extramural) session of the Asgardian Parliament. On January 8, 2019, the Higher Space Council of Asgardia was established by Decree No 28 of the Head of the State. On January 10-12, 2019, the third (digital, correspondence) session of the Asgardian Parliament was held; the acting ministers of finance, science, citizenship, culture, security, as well as trade and commerce were appointed.

On January 28, 2019, by Decree No 30 of the Chapter, the symbols of Asgardia were officially approved: a flag, a coat of arms and an anthem being previously approved by the Parliament, and which have already been used since autumn 2017.

In 2019, efforts were made to find ways for Asgardia to be recognized by other countries (participation of the delegation in the Davos Economic Forum, meeting with the representative of the royal family of Great Britain, etc.). On April 10-12, 2019, the fourth (digital, correspondence) session of the Parliament of Asgardia was held, all the ministers of 
the Government and the first congress of the leadership of Asgardia were elected, where the strategy and plans for the development of Asgardia were considered and adopted. The birth of the first human child in space is proclaimed as a priority goal [Asgardia].

For a more detailed description and analysis of the idea, process and problems of creating Asgardia, see: [Krichevsky, 2017-2019].

\subsection{Constitutional Foundations: Core Values, Virtual Citizenship, Extraterrestrial Territory and Capital of Asgardia}

In Art. 3 of the Constitution of Asgardia the mission of the state if formulated as "the existence and development of the Space Kingdom of Asgardia and the new cosmic humanity" [Constitution of Asgardia, 2017]..$^{5}$

In the Preamble of the Constitution of Asgardia, it is stated that it seeks to "unite the future humanity as transethnic, transnational, transreligious, ethical, fair, peaceful, looking into the infinite Universe, based on equality and dignity of every human being; resolve differences, conflicts, inequality and imperfections in human history, bring spiritual and scientific practices and human creative achievements to a new level in all their civilizational and cultural multitude, and launch a new era in the history of space humanity."

The Constitution of Asgardia is interesting in terms of the allocation of absolute core value and other core values of the state, some of which are directly related to space activities and are absent in the constitutions of other countries.

All these values are considered as a reflection of human values and the basis of the functioning of the digital space state. In accordance with Clause 6 of Article 4, the core values of Asgardia act in relations with other people who are not citizens of Asgardia and states of the planet Earth, as well as in "communications with the alien intelligence in case of its discovery". One of the highest values being especially important for the further development of space is the state of the environment, "the ecology of space."

In clause 3 of Article 4 in the Constitution, the absolute highest value of Asgardia is highlighted, which is related to the cosmic condition of the state: "unstoppable worldview, world transformation and world creation, aspiration of humanity to the infinite future, infinite universe, and infinite new universes". The rule is that in the event of a conflict of core values in the course of their implementation, the conflict of values must be resolved in the spirit of the absolute core value of Asgardia, otherwise the absolute core value of Asgardia must act directly.

It is evident, unfortunately, that in this definition of absolute supreme value the absolute core values-priorities are not included: 1) human life, the survival of man and humanity; 2) preservation of the Earth, its biosphere as the basis of the origin and existence of man and humanity.

As a result, conflicts and contradictions arose in the Constitution, as a document assigned, first of all, for the current stage of the formation of the state and its foreseeable future, which will inevitably manifest itself in the practice and results of the development of Asgardia.

Asgardia is a digital state with living citizens on Earth. The Constitution of Asgardia contains an unusual position for earthly constitutions, the special nature of the Asgardia citizenship, which does not give rise to supposedly multiple citizenship.

In his treatise "To the Eternal Peace" (1795), Immanuel Kant admitted the parallel existence in the future of the citizenship of specific (national) states and the citizenship of

${ }^{5}$ Hereinafter, references to the Constitution of Asgardia are given in the text indicating the preamble, subparagraphs, clauses and articles of the Constitution according to this source. 
the world federation as the right of hospitality to all in any part of Earth. This federation, according to the thinker, is established on the planet to ensure universal peace (see: [Kant, 2004]). Asgardia proposes a model with virtually special, i.e. non-touching dual citizenship in different realities, where the second, digital citizenship were in another dimension and allegedly did not affect the citizenship of other countries.

\subsection{Contours of the constitutional model of the system of state bodies of the digital space state of Asgardia}

The Constitution, adopted by the electron vote of citizens, contains the provision that the state power in Asgardia is carried out by citizens with the help of such a form of direct democracy as referenda (Clause 1 Article 30).

At the same time, the system of state bodies of Asgardia is created on the basis of the Constitution in order to implement numerous tasks the space state faces. Compared with the cosmic state of the Earth, even in terms of security, the Constitution proclaims (as yet declaratively) more complex cosmic tasks. Thus, according to Clause 1 Article 22, the state undertakes to "ensure the maintenance and protection of state sovereignty, the security of the state and its resources on space bodies, in space and on Earth with all available state resources, means and measures." However, these tasks will be solved only with the availability of appropriate funds.

Special article 24 of the Constitution "Protection of Earth" is about the protection of the Earth from threats from outer space. It is stated that for this purpose, Asgardia will use state and private resources to build and operate the planet Earth's defense systems, both independently and in conjunction with the states of the planet Earth and international organizations. In order to "preserve humanity and biodiversity of Earth, Asgardia shall organize and ensure the building of "Space Arks" - protective platforms in space to be used in the event of threats to the safety of humanity on Earth and for space tourism, in the absence of threats" (Clause 3 Article 24). This activity will require significant resources, special high-tech industrial production of space technology. Obviously, all this is impossible without cooperation with other states, which implies the official recognition of Asgardia.

In order to protect the Earth and its orbital satellite constellation Asgardia from threats from the Cosmos, the creation of a so far non-existing airspace fleet is proclaimed (Clause 1 Article 25). Asgardia is expected to act in conjunction with other earthly states and international organizations to safeguard Earth from space-originating threats.

One of the main goals of Asgardia's foreign policy is its international legal recognition. In foreign policy, the desire to "achieve a balance of general space and planetary interests, and its national interest" is declared (Clause 4 Article 29).

The state of Asgardia, according to the Constitution, operates in accordance with the principle of division of power into legislative, executive and judicial, while the power of the Head of State is not assigned to any of the branches of the government. The Head of State is the highest official of Asgardia.

Meetings of all governmental bodies can be of two types: in-person and correspondence with the use of electronic technologies.

In general, in the Asgardia's ideology and system of state bodies, among the traditional structures and functions of Earth, there are some important, absent from the earthly states and, possibly, useful ones for future cosmic states. 


\subsection{Asgardia as an experiment in modeling the digital space state}

The appearance of Asgardia stirred up the public consciousness on the eve of the new wave of space exploration, which rises before our eyes.

The Asgardia project stimulates research in the sphere of space activities, giving a new impetus to interdisciplinary research of the whole complex of problems associated with space exploration [Krichevsky, 2017].

Creation of Asgardia is not only a reflection of the dreams of humanity about Heaven, the Cosmos, its infinity and eternity, this is one of the forms of political unification of the people of Earth, their rapprochement, the promotion of their mutual understanding and mutual respect. Potentially similar organizations can act as peculiar "melting furnaces" for the unification of humanity, the creation of space civilization.

Encouraging Russians to join Asgardia, in June 2018, the first woman cosmonaut Valentina Tereshkova claimed: "People need to do a lot to learn to listen and understand each other. Our task is to overcome distrust, misunderstanding and show how beautiful and fragile our planet is, and we intend to protect it and defend it as a part of the vanguard group of humanity, which can be considered as all Asgardians. Join the ranks of digital Asgardia, take part in the construction of the Future Society. Let's make our planet and the space better together!'(Cited after: [Ashurbeyli, June17, 2018]).6

One of the positive experiments of Asgardia within the past three years was an attempt to create a new digital model of the association of people from different countries belonging to different denominations, who have different views as representatives of the single born cosmic civilization of the planet Earth. Igor Ashurbeyli, congratulating the Asgardians on the new 2019 year on the Eastern calendar, remarked: "Never before in the history of humanity, so many people of different races, nations and cultures united for the sake of one core goal the development of humanity and its expansion beyond the Earth. We are creating a new type of society. We have assumed a tremendous responsibility for the future of all civilization. Let us walk this way together, guided by the principle of Per Aspera ad Astra — "Through thorns to the stars!" [Ashurbeyli, 2019].

Aliya Prokofieva, an expert and active member in private cosmonautics, in a popular review of the possible evolution of power systems in the future, identified the following forms: noocracy (power based on the priority of intelligence), cyberocracy (with overcoming the bureaucracy of people as a "class"), autocracy of artificial intelligence (with uncertain multi-variant consequences for man and humanity), as well as the emergence of a multimedia system of virtual states that are not tied to a specific territory, giving people the choice between their codes of rights and duties (which will go into dissonance with the modern system of states with a more rigid organizational structure). Summing up the review of the possible variants of the evolution of power, Aliya Prokofieva writes: "The basic law of dialectics asserts that the form and content are united. Consequently, the fundamental shifts that occur today in the content of social relations will inevitably follow the rapid flowering of new forms of their organization, corresponding to the changed realities. More states, good and different! And Asgardia is just the first sign. Or Valkiriya?" [Prokofieva, 2018]. ${ }^{7}$

Another idea that is vague, but nevertheless emanates from Asgardia's documents, is, with the help of space states, the acquisition of statehood by nations which do not have their

\footnotetext{
${ }^{6}$ The picture of Valentina Tereshkova's original letter was published there, as well.

${ }^{7}$ Valkyrie in the Norse mythology flew over the battlefield and decided which warrior to remain alive and who would die, sometimes - who would win the battle. Warriors who died in battle went to heaven in Valhalla - a paradise for valiant warriors.
} 
own state on Earth and cannot exercise their right to self-determination. Igor Ashurbeyli, on his personal blog, remarked: "Asgardia will unite the representatives of all nations who aspire to self-determination in the narrow boundaries of earthly states. It is in Asgardia where they will get their freedom" [Ashurbeyli, 2019]. However, this is if Asgardia proves its own vitality during its development.

On the whole, the experimental avant-garde state of Asgardia is a new and interesting technology for organizing human society, largely remaining today as a declarative, utopian model for its ambitious, declared, yet unrealized, space objectives. In the case of its unlikely recognition by some states and development, it can open a "window of opportunity" to modify the system of state power. However, most likely, in the modern truncated form of the state, deprived of the real means of coercion, if necessary, the maintenance of compulsory order, Asgardia will be unable to provide substantial social, national and global security without the completion of some power structures at the present stage of historical development. Because of this, and also due to the fear of the emergence of many other unrecognized entities claiming state status in its model, it is unlikely that Asgardia will be recognized in the modern world community of the United Nations or by a group of earthly states. Nevertheless, the experience of Asgardia, this unique precedent, is important for modeling and forecasting possible directions and options for the evolution of space statehood in the future.

\subsection{Criticism of Asgardia's practical experience}

Criticism of several peculiarities of creation of institutions as well as negative moments from the on-hand experience of the state of Asgardia for 2016-2018 was first published by one of the authors of the article in early 2019 (see: [Krichevsky, 2019]).

Let us continue the critical analysis of experience. As of March 30, 2019, the Asgardian nation had approximately 1.05 million people from 200 countries of the world in terms of basic citizenship, of which 18.2 thousand are citizens and 275.5 thousand residents of the state (with a suspended status because of unpaid fees). The remaining ones ( 760 thousand) are in the status of supporters [Asgardia].

From April 1, 2019, in accordance with the Directive No. 1, the Government introduced new rules defining the status of a resident-citizen of Asgardia. ${ }^{8}$ As a result, only about 18.3 thousand of the Asgardia nation remained in the status of residents, $\sim 1.8 \%$ of the entire community, the remaining $\sim 98.2 \%$ will be able to become residents after paying a mandatory annual contribution of $€ 100$. Moreover, a citizen must pay another $€ 1000$ to become a certificate of residence of Asgardia.

It is worth noting that from the beginning, on October 12, 2016, when the Asgardia project was announced as an advertisement, the first 100 thousand participants ("the golden hundred") were said to obtain the right to preferential citizenship, i.e. without payment, in the future. This was confirmed before the referendum on the Constitution of Asgardia in June 2017. As a result, "the golden hundred" of the absolute majority did not become citizenresidents, apparently due to financial or other reasons, although thanks to their votes the Constitution was probably adopted as well as the Head of State and Parliament were elected. The benefits to "the golden hundred" need to be distributed not to those who have registered in the community but to those who have adopted the Constitution. If you adjust the rule of the "golden hundred", the number of citizens will increase and exceed 100 thousand.

\footnotetext{
${ }^{8}$ The main is stated in the Directive No. 1 of the Government of Asgardia, then on January 12, 2019 there was its correction [Asgardia].
} 
Thus, there has been a sharp and significant decrease in the number of residents, the division of the Asgardian community into two unequal parts: 1) "insignificant minority" citizen-residents of the state of Asgardia; 2) "absolute majority" — the remaining members of the Asgardian nation, retaining the ability to become citizen-resident of the state, but not yet eligible to participate in the elections.

The process of stratification goes fast within the state as well, among citizen-residents, there was defined the elite of $\sim 200$ people, i.e. $\sim 1 \%$ of citizens in governmental positions (Head of State, members of the Supreme Space Council, members of the Government, parliamentarians, etc.).

In practice, institutional development of the state of Asgardia goes with serious violations of the Constitution. The Supreme Space Council, without which it is impossible to govern the state, was created by the Head of State in January 2019, i.e. after 7 months after the inauguration of the Head. Presented for approval by the Parliament at the $4^{\text {th }}$ (digital, correspondence) session in April 2019, the list of 10 priority laws does not correspond to the laws necessary for the implementation of the Constitutional norms and the functioning of the state. Moreover, the drafts of the necessary laws are still absent (see: [Constitution of Asgardia, 2017]).

All this is a consequence of the features of the Asgardian state model, the manifestation of objective and subjective factors, excessive restrictions on the dissemination of information, because of incompetence, the conflict of interests of senior state officials that do not fully correspond to the positions occupied, who operate without control in the mode of virtually absolute power, violating the Constitutional norms, discrediting itself and the state of Asgardia. The Parliament has limited functions and capabilities; in fact, it cannot effectively influence events due to the features of the digital model, the technology of activities with the prevalence of distance correspondence communications in the conditions of multilingualism, other cross-cultural features, the negative influence on activities, working capacity of deputies of different time zones on Earth.

Thus, there are serious socio-political, economic and technological restrictions, including those connected with "closeness", "monarchy", "corporatization", conflict of interests, other features and tendencies of Asgardia. Therefore, unfortunately, it is unlikely that the new cosmic state under the influence of internal and external factors will not enter in the near future the stage of "saturation", stagnation and will not turn into a new specific corporation of Igor Ashurbeyli, his closest entourage and a limited number of loyal residents, and will be able to overcome the crisis, carry out a proclaimed high mission, grandiose plans for 25 years and will independently become a full-fledged cosmic humanity.

\section{Perspectives of the Space State}

\subsection{Prospects and limitations of the space state}

There are complex and interrelated philosophical, political, legal, technological and other aspects of the prospects and limitations of a space state.

As a complex and dynamic object of knowledge and control, the space state has its basic properties, contradictions, advantages, disadvantages, problems, while preserving the "birthmarks" of a state as the most important institution of modern society. At the same time, in the process of development, the space state on Earth and beyond acquires and manifests new and often contradictory properties, which are reflected in the experience and history of the space activities of many countries and the world community within the $20^{\text {th }}-21^{\text {st }}$ centuries. 
Resolving the contradictions of a space state, its transition into a new quality is possible in the process of the evolution of a man, state, society, civilization, including in the form of implementing one of the main scenarios for the evolution of a particular state: 1) sustainable development of specific space states; 2) their transformation into other space states, entry into a cosmic union, including possible interaction with extraterrestrial space states, civilizations, etc.; 3) degradation and transformation into a non-space state; 4) a disaster with the following decay and extinction.

There is a possibility of extreme variants of the state, transformation, "deformed" development of a space state; we denote them as "virtual", "imitative", "fragile", "parasitic", "highly specialized", "commercial", "corporate", "monopolized", "super-militarized", "totalitarian", "catastrophic", etc.

This is the problem of creating an "ideal space state" that stands out and can be recognized as a new, complex and topical one (by analogy, association with an "ideal state"), which is theoretically possible, but not achievable — not realizable in practice.

Balanced, sustainable, effective development of a space state in the interests of a man, society, civilization implies a desire for an ideal that can be represented as a complete (absolute) fulfillment of the space function through the use of new technologies, the coverage of the entire spectrum and cycle of space activities, including the achievement of high economic efficiency and environmental cleanliness (balance with the environment of Earth and space).

At the same time, there exists and evolves a complex system of constraints for the space state, due to internal and external, objective and subjective factors, including the volume, proportions, properties of resources allocated to the earth and space activities, the real efficiency of the space industry, features of the control system, the space market, international cooperation, geopolitical, military, ecological situation on Earth, etc.

Let us single out the technological aspect of the space state here, which is the key to "positive" evolution, the fulfillment of the space function and the realization of a promising Future. It covers a set of new technologies, including: 1) technology modeling of space technology and activities, the "rules of the game" of the space state and space humanity, etc.; 2) digital state and society; 3 ) the system of protection against asteroid-comet hazard (under the auspices of the $\mathrm{UN}^{9}$ and as a promising superglobal project of humanity); 4) universal space man, cosmonaut-quasi-man, cybernetic immortal man, cybernetic neocivilization, etc.; 5) eco-friendly (clean) space technologies and projects, etc. (see: [Krichevsky, 2012, 20172019]). The prospects for expanding the use of artificial intelligence in government, legal regulation, military affairs, space activities, and the risks associated with this process are of similar importance, as well.

The above aspects of the prospects and limitations of a space state, the criteria for its perfection and efficiency, the optimality of forms and models for different space conditions, the tasks and levels of development of cosmic civilization, as well as the problems of a universal space state, the world cosmic union of humanity, etc. have to be further modeled and researched. Among them are those, which apply the approaches and classifications proposed by the authors (see Introduction, Section 1, as well as paragraphs 4.2, 4.3 of part 4).

${ }^{9}$ In December 2016 the United Nations General Assembly adopted resolution A/RES/71/90, declaring 30 June International Asteroid Day ... to raise public awareness about the asteroid impact hazard (Cited after: [United Nations. International Asteroid Day 30 June. https://www.un.org/ en/events/asteroidday/]). 


\subsection{Space State and the Cosmic Union of Humanity}

A new era of international cooperation in the exploration of the cosmos is coming; i.e. the theses of Andrei Ionin [Ionin, 2019] are devoted to this.

In the perspective, the World Cosmic Union of Earth Communities seeking to explore space under the UN auspices will be created - a new network structure based on openness, voluntariness, equality (see: [Krichevsky, 2019]). The union of several space states of Earth can become its core, and Asgardia can enter it, as well.

The goal and form of the Cosmic Union of Humanity is not a rigid "vertical", but a common net "framework" targeted at space exploration, managed in the form of "guided development" (according to Nikita Moiseev, 1999).

It is necessary to develop and adopt the Universal Declaration of the World Cosmic Union for the exploration of space and the creation of cosmic humanity (other versions of the form and name of the act are possible).

This approach provides new directions and opportunities for the formation and transformation of space states in the paradigm of cosmic humanity as a new cosmic civilization based on earth civilization (see: [Krichevsky, 2019]).

At the same time, aggravation of contradictions and competition is possible between earthly "ordinary" and space states, between "old" and new space states among themselves in order to gain leadership and resources, as well as in the new World Cosmic Union.

Millions of people on Earth, especially young people, are passionate about the idea of space exploration and the cosmic future of man and humanity. There are thousands of space communities, a new Asgardia community is developing, in which $>1$ million people are creating a fundamentally new space state and a cosmic nation. Astronautics, real space activities gave an idea of the limitless possibilities of man and humanity in the development of fundamentally new space technologies and space exploration, including space expansion in the future, i.e. resettlement beyond Earth, the possibility of colonization of the Moon and Mars as well as the creation of cosmic humanity.

To realize promising space future, the world community needs the effective development of space activities, the space industry in earthly states, countries and beyond the Earth's borders, the new "space treaty" on the World Cosmic Union and other strategic decisions that go beyond the scope of space activities aimed at achieving peace on Earth and in Space under difficult conditions of a new reality and global crisis.

Then the Space Age of humanity will acquire new meanings and goals and will be continued with the implementation of superglobal projects based on the new "rules of the game" and technologies.

There will be a difficult and long transition period from confrontation and competition of states, space states in a divided earthly community to the creation of a common structure and institutions of space exploration of united humanity with the transformation of states into other structures in the process of evolution of cosmic humanity — space civilization.

\subsection{Universal Space State: Futurological Aspect}

The scientific, technical, economic, social evolution of human civilization will be accompanied by changes in its organizational form of the state, in particular.

At a later stage of the evolution of cosmic civilization, most likely on the basis of numerous earthly states, something like the state of the united nations of Earth will arise, i.e. 
in the form of a federation (with functioning within this federation as its members, which have preserved and developed national states and their unions by that time).

For some long period of the historical development of space civilizations, their organizational form will be a developing state as a "universal space state" that changes forms, methods of performing functions and that expands the space of functioning and participation, in perspective and in interaction with other civilizations. However, it is possible that at some more distant stage of the evolution of space civilization, its organizational forms can be significantly transformed into still unknown to us.

The space civilization of humanity of Earth needs to further study and explore the Solar system and far space - other star systems, their space objects, interstellar space in our Galaxy, colonize and transform space. The organization, coordination of this process of space expansion, control over it, the provision of a rational order, may be carried out in the future by a highly developed control system using artificial intelligence, which is even difficult to imagine today, the prototype of which is modern emerging space states.

As civilization develops, the space state will function in an ever-increasing outer space, but it will never be able to streamline the entire cosmos. Knowledge and order of the cosmos are apparently inexhaustible even for much more developed space civilizations. However, without a space state, humanity will not be able to solve many problems that will confront it in space exploration, the evolution of the mind and the Universe.

The most typical forms of strong, powerful space states of the more distant future can be assumed to be state forms that maximize the use of the capabilities of artificial intelligence and robots, ensure a strong central authority (presidential republics, constitutional monarchies, presidential-parliamentary republics, etc.), rigid order in high-tech society, reliable control in the vast space of the Cosmos. At the same time, it is possible to combine a strong central authority with the optimal autonomy of local authorities (for example, in remote communities established on separate planets, in other star systems).

Initially, at the stage of the formation of space states on Earth or from earthly states, all of them will be connected with Earth in one way or another. In a more distant, although already relatively foreseeable perspective today, space states can also bud off earth (earth-space) states and become non-terrestrial. They can appear, for example, on the basis of Humanity 2, Humanity - 3, which are far from Earth and autonomous space settlements, etc. (or, taking into account the possible evolution of humanity, may be post-humanity: Post-humanity -2 , Post-humanity - 3, etc.).

It is possible that such formation of new states or the separation of the former ones, the separation of independent states from them, may in some cases be painful, accompanied by crises, conflicts, struggle against "space separatism", the prevention or suppression of such attempts. In some cases, such attempts can be stopped, considered illegitimate, but in other situations they can be successful and necessary, recognized by all or many. However, at such a high level of the development of humanity, its cosmic civilization, such events, presumably, will be carefully calculated, coordinated if necessary, planned and organized in order to eliminate serious negative consequences.

The evolution of space states, in general (or cosmic forms of political power), with the technological development of space civilization, will apparently correspond to the expansion of outer space covered by its activities. In this regard (as a complete model and a distant forecast), one can speak of different levels of space civilization activities and, accordingly, of space states - the planet Earth, the Solar system, the interstellar system, the Galaxy sector, the entire Galaxy, etc. 
In general, the formation of space states opens up new development opportunities for humanity, but does not eliminate the risks and threats to civilization. There are new contradictions and challenges (including the danger of space wars). Obviously, not all cosmic civilizations are destined to go through a difficult and dangerous path to the heights of evolution. How the history of humanity will evolve, the subjects of which the space states will be, will depend on many objective and subjective factors that have yet to be investigated.

\section{Key findings and recommendations}

1. Philosophical, legal, historical, technological aspects of the theory and practice of the space state, basic concepts, classifications, models are considered, examples are given, predictions are made. The general classification of organizations that are involved in space activities for the purpose of survival and development on Earth and Beyond as well as universal classification of space states are developed and presented.

2. Having entered the Space Age of development, humanity has entered the era of the formation of space statehood, the space state is a natural stage of evolution. The further evolution of the state and society will be associated with the gradual discovery of new aspects, facets, levels, and capabilities of their space potential.

3. Considering the increasing scale of the space state's activities, its resources, scientific, technical and energy equipment, it must inevitably be a strong and legal state. A weak space state is not able to effectively fulfill the cosmic function of the society.

4. The development of the space state opens up new opportunities for humanity, but it also creates new contradictions and creates new risks. Entry into space of the armies of the opposing states, especially in the process of competition for the development of space resources, will create a new sphere of confrontation, conflicts and military clashes. At the same time, the infinity of space resources can serve as a factor in changing the vector of competition into the outside. Large-scale and costly space projects, the need for jointly solving the problems of space security will contribute to the pooling of efforts and resources of different countries, their integration into alliances and new united states and alliances.

5. A brief analysis of the project, history, experience of creating the first digital space state of Asgardia, its Constitution, political, social, legal philosophy and management system was carried out. The system of core values and the absolute core value of Asgardia are of particular interest, but the definition of the absolute core value in the Constitution does not take into account the goals and prospects of man and humanity.

6. Asgardia, as an avant-garde and truncated project of an artificially and rapidly formed new space state, reflects the general trend of the statehood evolution, its new forms and management technologies of the 21 st century. Some of the elements of Asgardia may turn out to be prototypes of the future structures of space states. At the same time, there are a number of utopian, unrealistic provisions in the Constitution and plans of Asgardia, which are not secured at present and in the near future with financial, scientific, technical and technological capabilities.

7. A critical analysis of the practice of creating the space state of Asgardia for the period 2016-2019 is made.

8. Philosophical and technological aspects of the perspectives and limitations of the space state, philosophical and legal, technological aspects, including a new era of international cooperation, taking into account the possibilities of creating the World Cosmic Union, are briefly reviewed, the futurological aspect of the universal space state is considered. 
9. It is advisable to continue the study of the philosophical foundations, legal and interdisciplinary aspects of the space state on Earth and Beyond, the process of its evolution, new models in the context of the theory and practice of cosmic humanity creating.

\section{$\mathbb{E}[\mathbb{l}$ References}

Asgardia. The Space Nation, 2019. https://asgardia.space/en/

Ashurbeili, Igor' Raufovich. Oficial'nyi sait, 2019. https://www.ashurbeyli.ru/

Baturin, Yuri. Simulation as an auxiliary tool of history of science and technology. Herald of the RAS. Vol. 83. № 1. 2013: 3-9. (In Russian).

Belyaev, Sergei. Perspektiva blagozhelatel'noi diktatury. Nezavisimaya gazeta. 11.03.2019. http://www.ng.ru/ideas/2019-03-11/5_7527_perspective.html (In Russian)

Borovoj, Alexey. Lichnost' i obshestvo v anarhistskom mirovozzrenii. Peterburg — Moskva: Golos truda, 1920.

Constitution of Asgardia - The Space Kingdom, 2017. https://asgardia.space/en/vote/ constitution/

Fedorov, Nikolaj. Stat'i o regulyacii. Soch. Moskva, 1982. (In Russian).

Fukuyama, Frensis. Sil'noe gosudarstvo. Upravlenie i mirovoi poryadok v XXI v. Moskva: AST, 2010. (In Russian).

Egorov, Vitalii. Novye kosmicheskie derzhavy. 14.01.2018. https://nauka-pro.ru/novyekosmicheskie-derzhavy (In Russian).

Ivanov, Vladimir. Blagopoluchie Ameriki ne budet vechnym. Razvedchiki preduprezhdayut o ser'eznom roste ugroz nacional'noi bezopasnosti SShA. 22.02.2019. Nezavisimoe voennoe obozrenie. http://nvo.ng.ru/spforces/2019-02-22/12_1035_eternity.html (In Russian)

Ionin, Andrey. Mars - nash. Obshchiy. Shest aprelskikh tezisov v obosnovaniye mezhdunarodnogo kharaktera programm osvoyeniya dalnego kosmosa. Novaya gazeta. 7.04.2019. https://www.novayagazeta.ru/articles/2019/04/07/80127-marsnash-obschiy (In Russian).

Ivanova, Lidiya, and Sergey Krichevskiy. Soobshchestvo kosmonavtov. Istoriya stanovleniya i razvitiya za polveka. Problemy i Perspektivy. Predisl. Viktora Savinyih. Moskva: LIBROKOM, 2013. (In Russian).

Kaku, Mitio. Budushee chelovechestva: Kolonizaciya Marsa, puteshestviya $k$ zvezdam $i$ obretenie bessmertiya. Moskva: Al'pina non-fikshi, 2019. (In Russian).

Kant, Immanuil. Ideya vseobshei istorii vo vsemirno-grazhdanskom plane. K vechnomu miru. Vstupit. st. i primech. S.F. Udartseva. Izd. 2-e. Almaty: Zheti Zhargy, 2004 (In Russian)

Kerimov, Aleksandr, and Ivan Kuksin. Sil'noe gosudarstvo. Moskva: Norma: INFRA-M, 2017. (In Russian).

Krichevsky, Sergey. Aerospace Activities: Interdisciplinary Analysis. Moscow: LIBROKOM, 2012. (In Russian).

Krichevsky, Sergey. Cosmic Humanity: Utopia, Realities, Prospects. Future Human Image. 7, 2017: 50-70. (In Russian).

Krichevsky, Sergey. Super Global Projects and Environmentally Friendly Technologies Used in Space Exploration: Realities and Prospects of the Space Age. Philosophy \& Cosmology. Vol. 20, 2018: 92-105.

Krichevsky, Sergey. Cosmic Union of Communities: a New Concept and Technologies of Creating Cosmic Humanity. Philosophy and Cosmology, Volume 22, 2019: 33-50. https://doi.org/10.29202/phil-cosm/22/4 
Kukieva, Anel'. Etapy institucional'nogo razvitiya kosmicheskoi otrasli Kazahstana. Pravo i gosudarstvo. № 3-4, 2017: 197-207. (In Russian).

Malko, Aleksandr, and Viktor Zatonskii. Pravovaya politika v sfere formirovaniya sil'nogo gosudarstva. Pravo i gosudarstvo. № 1-2, 2018: 23-34. (In Russian).

Medvedev, Sergei. Sleduyushaya ostanovka - Luna. 03 fevralya 2019. Radio Svoboda. https://www.svoboda.org/a/29742482.html

Moiseev, Ivan. Space market: structure and trends. Eurasian financial \& economic herald. 1, 2019: 32-36. https:/www.fbacs.com/images/Herald-c-2019.pdf

Ponkin, Igor. Sil'noe gosudarstvo. Pravo i gosudarstvo. № 1-2 (78-79), 2018: 53-70. (In Russian).

Prokofieva, Aliya. Gosudarstvo budushego: volya razuma ili svoboda vybora? // VC.ru. 16 avgusta 2018. https://vc.ru/flood/43842-gosudarstvo-budushchego-volya-razuma-ilisvoboda-vybora (In Russian).

Tabanbaeva, Aischabibi. Formirovanie nacional'nogo zakonodatel'stva o kosmicheskoi deyatel'nosti v zarubezhnyh stranah. Pravo i gosudarstvo. № 3-4. 2017: 169-185. (In Russian).

Tsiolkovskij, Konstantin. Volya vselennoi. Neizvestnye razumnye sily. Kaluga, 1928. (In Russian).

Tsiolkovskij, Konstantin. Volya vselennoi. Moskva: AST, 2019. (In Russian).

Udartsev, Sergei. Politicheskaya i pravovaya teoriya anarhizma v Rossii: istoriya i sovremennost'. Almaty: «Kazahstan»; Vysshaya shkola prava «Adilet», 1994. (In Russian).

Udartsev, Sergey. Ideya kosmicheskogo gosudarstva v istorii politicheskoi mysli. Pravo $i$ politika. № 8, 2012: 1386-1398. http://nbpublish.com/ view_post_368.html (In Russian).

Udartsev, Sergey. Cosmic state: the forming and development of the idea in the history of thought. SENTENTIA. European Journal of Humanities and Social Sciences. № 1, 2014: 37-50. https://doi.org/10.7256/1339-3057.2014.1.11412.

Udartsev, Sergey. Kosmicheskoe gosudarstvo kak gosudarstvo budushego: vozmozhnye varianty formirovaniya i yuridicheskogo zakrepleniya statusa. Pravovaya kul'tura. Nauchnyi zhurnal = The Legal Culture. Scientific journal. № 1, 2019a: 23-37. (In Russian).

Udartsev, Sergey F. Space State: Possible Options for Forming. RUSSIAN LAW: Theory and Practice. № 1, 2019b: 66-75.

United Nations. International Asteroid Day 30 June. https://www.un.org/en/events/asteroidday/

Ursul, Arkady. Perehod Rossii k ustoichivomu razvitiyu. Noosfernaya strategiya. Moskva: ID "Noosfera", 1998. (In Russian).

Ursul, Arkady. Space exploration in sustainable development strategy. Actual problems of aviation and aerospace systems: processes, models, experiment. Vol. 21, № 1. 2016: 206-210.

Ursul, Arkady, and Tatiana Ursul. Universal (Global) Evolutionism. Philosophy and Cosmology. 20, 2018: 33-41. https://doi.org/10.29202/phil-cosm/20/3

Vaganov, Andrei. Prygnut' na Mars, ottolknuvshis' ot Luny. Nezavisimaya gazeta. 22.01.2019. URL: http://www.ng.ru/science/2019-01-22/9_7488_mars. html (In Russian).

Zhukov, Sergey, and Ivan Moiseev. U istokov rossiiskogo kosmicheskogo zakonodatel'stva. Pilotiruemye polety v kosmos. № 4, 2018: 99-118. (In Russian). 